\title{
Penangkaran Burung Walet Perspektif Etika Bisnis Islam
}

\author{
Ahmad Mas'ari ${ }^{1}$, Harpito $^{2}$ \\ ${ }^{1,2}$ Jurusan Teknik Industri, Fakultas Sains dan Teknologi, UIN Sultan Syarif Kasim Riau \\ Jl. HR. Soebrantas No. 155 Simpang Baru, Panam, Pekanbaru, 28293 \\ Email: ahmad..mas’ari@uin-suska.ac.id
}

\begin{abstract}
Abstrak
Bagaimana pandangan hukum Islam terhadap praktik bisnis penangkaran burung walet dan mengkonsumsi air liur walet? Pertanyaan inilah yang menjadi latar belakang penelitian ini. Penelitian ini sepenuhnya merupakan riset kepustakaan (library research). Pendekatan yang digunakan dalam penelitian ini adalah pendekatan normatif. Jenis data dalam penelitian ini adalah kualitatif. Adapun teknik pengumpulan data dalam penelitian ini adalah dengan cara mencari dan menggali referensi yang ada kaitannya dengan masalah yang diteliti, baik yang berbentuk buku, artikel maupun dalam bentuk pemberitaan di media massa. Adapun teknik analisis data yang digunakan adalah teknik content analysis (analisa isi). Kesimpulan dari penelitian ini adalah bahwa memelihara burung itu hukumnya diperbolehkan, termasuk memelihara burung walet meskipun hanya sekedar untuk menikmati keindahan suaranya,bulu-bulunya atau sekedar untuk bersenang-senang asalkan pemilik burung merawatnya dengan baik, dengan mencukupi keperluan makanan dan minumannya, dan pada prinsipnya hukum mengkonsumsi sarang burung walet dibolehkan (halal), karena sarang burung tersebut dihasilkan dari bagian dalam perut burung tersebut.
\end{abstract}

\section{Latar Belakang}

Salah satu peluang bisnis yang sangat menjanjikan dan banyak orang geluti saat ini adalah penangkaran burung walet. Burung walet biasanya hidup di gua-gua dan mempunyai kemiripan dengan burung layang-layang, dalam hal memangsa serangga ketika terbang. Menagkar burung walet bukan dimaksudkan untuk dijual dan dinikmati suaranya, bukan juga untuk dimakan dagingnya, melainkan untuk dijual sangkarnya. Sangkar tersebut mengandung air liur burung tersebut. Penduduk di negara-negara seperti Jepang, Hongkong, Taiwan, Tiongkok telah lama mengkonsumsi sarang burung tersebut karena dipercaya memiliki banyak khasiat. Biasanya cara mengkonsumsinya dengan cara dibuat sop. Sop sarang burung walet telah dikonsumsi oleh orang-orang China selama ribuan tahun. (Arief Budiman, 2005: 42).

Seiring dengan meningkatnya perekonomian China, permintaan sarang burung walet juga semakin meningkat. Oleh sebab itu, industri sarang walet di Asia dan terutama di Indonesia juga mengalami dampak kenaikan. Sop sarang burung walet adalah salah satu jenis makanan yang mempunyai tanda kebesaran di China, sehingga banyak peminatnya terutama berasal dari China. Perdagangan sarang walet mulai berkembang di China pada masa Dinasti T'ang pada tahun 618-907. Pada abad ke-20 pemerintah komunis China melarang masyarakat China untuk memakan makanan yang mahal dan istimewa seperti sop sarang burung walet. Tetapi pada abad akhir ke-20 pemerintah China menjadi lebih bebas sehingga pemintaan sarang burung walet kembali meningkat. (Arief Budiman, 2005: 47).

Gambaran peluang agribisnis sarang burung walet merupakan komoditi ekspor yang bernilai tinggi. Kebutuhan akan sarang burung walet di pasar internasional sangat besar dan masih kekurangan persediaan. Hal ini disebabkan oleh masih kurang banyaknya budidaya burung walet. Selain itu juga produksi sarang walet yang telah ada merupakan produksi dari sarang-sarang alami. Peternakan burung walet sangat menjanjikan bila dikelola dengan baik dan intensif.

Indonesia adalah negara yang menghasilkan sebagian besar sarang burung walet di dunia. Negara-negara lain yang juga menghasilkan sarang burung walet adalah Thailand, Malaysia, Filipina, Vietnam, Burma, Singapura, India dan Srilanka. Semua negara ini terletak di Asia Selatan dan Asia Tenggara. Di Indonesia sebagian besar sarang burung walet dihasilkan dari budidaya dengan menggunakan gedung walet. (Eka Adiwibawa,2000: 72).

Hasil dari peternakan walet ini adalah sarangnya yang terbuat dari air liurnya (saliva). Harga sarang burung walet itu sangat pantastis, berkisar antar 6-14 juta Rupiah per kilonya. Tergantung kepada kualitas sarang tersebut. 
Sarang walet ini selain mempunyai harga tinggi, juga dapat bermanfaat bagi duni kesehatan. Sarang walet berguna untuk menyembuhkan penyakit paru-paru, panas dalam, melancarkan peredaran darah dan penambah tenaga.

Burung walet lazimnya membuat sarang di atap gua, sehingga untuk mengambil sarang burung walet sangatlah sulit dan berbahaya. Burung walet juga membuat sarang di dalam rumah-rumah yang kosong. Karena budidaya burung walet di dalam rumah-rumah kosong adalah metode yang sangat efektif untuk menghasilkan sarang tersebut, orang-orang mulai membuat gedung khusus untuk budidaya sarang burung walet.

\section{Rumusan Masalah}

Berdasarkan pada latar belakang masalah yang telah diuraikan di atas, maka penulis dapat mengambil rumusan masalah yaitu bagaimana pandangan hukum Islam terhadap praktik bisnis penangkaran burung walet dan mengkonsumsi air liur walet?

\section{Tujuan Penelitian}

Penelitian ini dilakukan dengan tujuan menemukan jawaban atas pertanyaan bagaimana pandangan hukum Islam terhadap praktik bisnis penangkaran burung walet dan mengkonsumsi air liur walet.

\section{Manfaat Penelitian}

1. Secara operatif, tujuan penelitian ini ingin memperoleh jawaban mendalam mengenai tinjauan hukum Islam terhadap praktik bisnis penangkaran burung walet dan mengkonsumsi air liur walet.

2. Secara teoritis, hasilnya merupakan kontribusi bagi pengembangan pemikiran di bidang keagamaan, khususnya dalam bidang etika bisnis dan ekonomi syariah.

3. Secara praktis dapat dijadikan landasan (dasar) untuk mengadakan penelitian lanjutan dalam bidang yang sama.

\section{Batasan Masalah}

Penulis membuat batasan masalah agar pembahasan lebih terarah dan tidak terlalu luas cakupannya. Maka penulis membatasi masalah yang diteliti pada pandangan hukum Islam terhadap penangkaran burung walet, dan hukum mengkonsumsi sarang walet.

\section{Tinjauan Pustaka}

\section{Kriteria Hewan Halal Perspektif Hukum Islam}

Binatang yang halal adalah binatang yang boleh dimakan dagingnya menurut syariat Islam. Binatang yang halal tersebut adalah sebagai berikut:

a. Binatang halal berdasarkan dalil umum dari al-Qur'an dan hadis.

Dalil umum yang dimaksud di sini adalah dasar yang diambil dari al-Qur'an dan hadis yang menunjukkan halalnya binatang tersebut secara umum. Adapun yang termasuk jenis binatang halal berdasarkan dalil umum adalah:

1. Binatang ternak darat. Jenis-jenis binatang ternak darat seperti: kambing, domba,sapi, kerbau, dan unta. Hal ini berdasarkan firman Allah: “....dihalalkan bagimu binatang ternak ... (QS. AlMaidah [4]: 1).

2. Binatang laut (air). Semua binatang yang hidupnya di dalam air baik berupa ikan atau lainnya, kecuali yang menyerupai binatang haram seperti anjing laut, menurut syariat Islam hukumnya halal dimakan. Berdasarkan firman Allah: "Dihalalkan bagimu binatang buruan laut dan makanan yang berasal dari laut yang lezat bagimu dan orang-orang yang sedang dalam perjalanan ...". (QS. AlMaidah [4]: 96). Maksudnya adalah binatang buruan laut yang diperoleh dengan jalan usaha seperti mengail, memukat, dan sebagainya, termasuk juga dalam pengertian laut di sini adalah sungai, danau, kolam, dan sebagainya.

3. Binatang halal berdasarkan dalil khusus. Adapun yang dimaksud dengan dalil khusus adalah dalil yang langsung menyebut jenis binatang tertentu. Yang termasuk jenis binatang halal yang langsung disebut melalui dalil tertentu, seperti: kuda, keledai liar/himar, ayam, belalang, dan kelinci.

b. Binatang halal berdasarkan Pendapat/Fatwa ulama

1. Musang. Musang adalah halal, karena walaupun bertaring hanya saja dia tidak menakuti dan memangsa manusia atau hewan lainnya dengan taringnya dan dia juga termasuk dari hewan yang baik. Ini merupakan menurut mazhab Malikiyyah, Syafi'iyyah, dan salah satu dari dua riwayat dari Imam Ahmad. (Khatib Syarbini, Mughniy al-Muhtaj, 4/299).

2. Tupai/ Bajing. Ulama berbeda pendapat tentang hukum makan tupai. Jumhur (mayoritas) ulama berpendapat bahwa makan tupai hukumnya halal. Sementara sebagian ulama berpendapat haramnya tupai, karena hewan ini 
mengigit dengan taringnya. Pendapat kedua ini merupakan pendapat mazhab Hanafi dan sebagian ulama Syafi'iyah dan Hanabilah. Sementara Malikiyah berpendapat makruh. Pendapat yang lebih kuat adalah boleh. Hukum memakan tupai adalah kembali ke hukum asal segala sesuatu yakni halal, selama tidak membahayakan kesehatan. Sebab, memang tidak ada dalil, baik dari al-Qur'an dan sunnah tentang pengharamannya, atau makruhnya. (Ibnu Rusyd, Bidayah al-Mujtahid, 2/101).

3. Landak. Hukum landak, mayoritas ulama memandangnya sebagai hewan yang halal untuk dimakan, sedangkan sebagian lagi memakruhkan namun ada pula yang mengharamkannya. Adapun yang menghalalkan landak adalah Imam Syafi'i dan para pengikut mazhabnya, Imam Laits bin Sa'ad, dan Imam Abu Tsaur. Demikian pula sebagian mazhab Hanbali seperti Imam al-Syaukani dan Imam al-Shan'ani. Sedangkan dari kalangan Maliki ada beberapa riwayat pendapat, tetapi yang kuat mazhab ini membolehkan memakan landak. (Ibnu Rusyd, Bidayah al-Mujtahid, 2/112).

Sedangkan binatang yang diharamkan adalah binatang yang tidak boleh dimakan berdasarkan hukum syariat Islam. Jenis-jenis binatang haram adalah sebagai berikut:

a. Binatang yang diharamkan dalam penjelasan al-Qur'an

Binatang yang diharamkan dalam penjelasan al-Qur'an, yaitu binatang yang disebutkan pada al-Qur'an surah al-Maidah ayat 3: "Diharamkan bagimu (memakan) bangkai, darah, daging babi, daging hewan yang disembelih atas nama selain Allah, yang tercekik, yang terpukul, yang jatuh, yang ditanduk, dan diterkam binatang buas, kecuali yang sempat kamu menyembelihnya, dan (diharamkan bagimu) yang disembelih untuk berhala." Dikecualikan darinya tiga bangkai, yaitu: (1) Ikan, karena dia termasuk hewan air. Semua hewan air adalah halal bangkainya, kecuali kodok. (2) Belalang. Berdasarkan ucapan Ibnu Umar: "Dihalalkan untuk kita dua bangkai dan dua darah. Adapun kedua bangkai itu adalah ikan dan belalang. Dan adapun kedua darah itu adalah hati dan limfa”. (HR. Ahmad dan Ibnu Majah). (3) Janin yang berada dalam perut hewan yang disembelih. Hal ini berdasarkan hadis yang diriwayatkan oleh Imam Ahmad dan Ashhab al-Sunan kecuali al-Nasa'i: "Penyembelihan untuk janin adalah penyembelihan induknya." Maksudnya jika hewan yang disembelih sedang hamil, maka janin yang ada dalam perutnya halal untuk dimakan tanpa harus disembelih ulang.

b. Binatang yang Diharamkan Menurut

Penjelasan Hadis

Binatang yang diharamkan menurut penjelasan hadis adalah khimar atau keledai jinak (Keledai Piaraan). Rasulullah Saw bersabda: "Saat (perang) Khaibar, kami memakan kuda dan keledai liar, dan Nabi melarang kami dari keledai jinak." (HR. Muslim).

c. Binatang yang diharamkan melalui dalil umum

Binatang yang diharamkan melalui dalil umum, yaitu dalil yang hanya menyebut sifat-sifat binatang. Binatang yang diharamkan berdasarkan dalil umum dengan menyebut sifat-sifat binatang yaitu; binatang buas yang bertaring, binatang yang memiliki cakar (cengkeraman), binatang yang makan kotoran, binatang yang dilarang membunuhnya, binatang yang disuruh membunuhnya.

1. Binatang buas dan bertaring

Binatang buas yang bertaring adalah yang taringnya digunakan untuk memangsa atau menerkam mangsanya. seperti singa, serigala, macann tutul, macan kumbang, anjing, kucing, beruang, buaya, monyet. Nabi bersabda: "Setiap binatang buas yang bertaring, haram dimakan" (HR. Bukhari dan Muslim). Ibnu Hajar al-Asqalani dalam Fath al-Bari mengatakan bahwa termasuk hewan yang dikecualikan dari kehalalan untuk dimakan adalah buaya karena ia memiliki taring untuk menyerang mangsanya.

2. Semua burung yang memiliki cakar/ berkuku tajam

Semua burung yang memiliki cakar yang kuat yang dia memangsa dengannya, seperti: elang, rajawali, kakatua, nasar, burung hantu. Nabi bersabda: "Rasulullah shallallahu 'alaihi wa sallam melarang memakan setiap binatang buas yang bertaring, dan setiap jenis burung yang mempunyai kuku untuk mencengkeram." (HR. Muslim).

3. Hewan yang dilarang untuk dibunuh Hewan dilarang untuk dibunuh seperti: semut, lebah, burung hud-hud, burung shurad (kepalanya besar, perutnya putih, punggungnya hijau dan katanya biasa memangsa burung pipit), dan katak. Nabi bersabda: "Nabi melarang untuk membunuh empat binatang, yaitu semut, 
lebah, burung hud-hud, dan burung shurad." (HR. Abu Daud, Ibnu Majah, dan Ahmad). Dalam sabda Nabi yang lain: "Sesungguhnya seorang tabib bertanya kepada Rasulullah tentang katak untuk keperluan obat, Rasulullah melarang membunuhnya" (HR. Al-Nasa'i). Keleawar juga haram dimakan menurut ulama Hanbali dan Syafi'iyah. Hal ini karena kelelawar dilarang untuk dibunuh sebagaimana disebutkan dalam hadis Nabi: "Janganlah kalian membunuh katak, karena suaranya adalah tasbih. Jangan kalian pula membunuh kelelawar, karena ketika Baitul Maqdis roboh ia berkata: Wahai Tuhan, berikanlah kekuasaan padaku atas lautan hingga aku dapat menenggelamkan mereka." (HR. AlBaihaqi).

4. Hewan yang diperintahkan untuk dibunuh

Hewan yang diperintahkan untuk dibunuh, seperti: ular, burung gagak, burung elang, kalajengking, tikus, dan anjing liar. Nabi bersabda: "Ada lima jenis hewan fasiq (berbahaya) yang boleh dibunuh ketika sedang ihram, yaitu tikus, kalajengking, burung rajawali, burung gagak dan kalb aqur (anjing galak)." (HR. Bukhari dan Muslim). Hewan yang digolongkan hewan fasik dan juga diperintahkan untuk dibunuh adalah cecak atau tokek. Hal ini berdasarkan hadis Sa'ad bin Abi Waqqosh, beliau mengatakan: "Nabi memerintahkan untuk membunuh tokek, beliau menyebut hewan ini dengan hewan yang fasik." (HR. Muslim).

5. Setiap binatang menjijikkan (khabits)

Khabits bermakna segala sesuatu yang merasa jijik untuk memakannya, seperti ular dan hasyarat (berbagai hewan kecil yang hidup di darat). Termasuk juga dalam kategori binatang ini adalah binatang-binatang yang kotor dan secara umum menjijikkan, seperti: lalat, tungau, kutu, kecoa, kumbang, cacing, bekicot, dan sejenisnya. Allah berfirman: "Dan dihalalkan bagi mereka segala yang baik dan diharamkan bagi mereka segala yang jelek (khabits)." (QS. Al-A'raf [7]: 157). Cacing adalah salah satu jenis hewan yang masuk ke dalam kategori al-hasyarat.

\section{d. Binatang yang hidup di dua alam}

Sejauh ini belum ada dalil dari alQur'an dan hadis yang shahih yang menjelaskan tentang haramnya hewan yang hidup di dua alam (laut dan darat). Dengan demikian binatang yang hidup di dua alam asal hukumnya adalah halal kecuali ada dalil yang mengharamkannya. Berikut contoh beberapa hewan hidup di dua alam dan hukum memakannya: (1) Kepiting hukumnya halal sebagaimana pendapat Atha' dan Imam Ahmad. (2) Kura-kura dan penyu juga halal sebagaimana mazhab Abu Hurairah, Thawus, Muhammad bin Ali, Atha', Hasan al-Bashri, dan fuqaha' Madinah. (Ibnu Hazm, alMuhalla, 6/84). (3) Anjing laut juga halal sebagaimana pendapat imam Malik, Syafi'i, Laits, Syai'bi, dan al-Auza'i. (Ibnu Qudamah, al-Mughni, 13/346). (4) Katak/kodok hukumnya haram secara mutlak menurut pendapat yang rajih (kuat) karena termasuk hewan yang dilarang dibunuh sebagaimana penjelasan di atas. (5) Buaya termasuk hewan yang haram karena memiliki taring yang kuat.

\section{Etika Bisnis dalam Ekonomi Islam}

Etika bisnis didefinisikan sebagai seperangkat nilai tentang baik, buruk, benar dan salah dalam dunia bisnis berdasarkan pada prinsip-prinsip moralitas. Dalam arti lain etika bisnis berarti seperangkat prinsip dan norma dimana para pelaku bisnis harus komit padanya dalam bertransaksi, berperilaku dan berelasi guna mencapai tujuan-tujuan bisnisnya dengan selamat. Hal ini yang menjadi kriteria penghargaan dan peringatan/tindakan (a set of principles and norms to which business people should adhere in their business dealings, conduct, and realtions in order to reach the shores of safety. It is also a criterion for reward or punishment). (Mustaq Ahmad, 2001: 31).

Dengan demikian, maka belajar etika bisnis berarti 'learning what is right or wrong' yang dapat membekali seseorang untuk berbuat the right thing yang didasari oleh ilmu, kesadaran, dan kondisi yang berbasis moralitas. Namun terkadang etika bisnis dapat berarti juga etika manajerial (management ethics) atau etika organisasional yang disepakati oleh sebuah perusahaan. (Faisal Badroen, 2006: 16). Kata bisnis di dalam Al-Qur'an yaitu al-tijarah dan dalam bahasa arab tijaraha, yang bermakna berdagang atau berniaga. Jadi, Etika Bisnis adalah standar-standar nilai yang menjadi pedoman atau acuan manajer dan segenap karyawan dalam pengambilan keputusan dan mengoperasikan bisnis yang etik. (Budi Untung, 2012: 61).

Sejumlah aksioma dasar (hal yang sudah menjadi umum dan jelas kebenaranya) sudah dirumuskan dan dikembangkan oleh para sarjana Muslim. Aksioma-aksioma ini merupakan turunan dari hasil penerjemahan kontemporer akan konsep-konsep fundamental dari nilai moral 
Islami. Dengan begitu, aspek etika dalam bahasan ini sudah di insert dan di internalisasi dalam pegembangan sistem etika bisnis. Rumusan aksioma ini diharapkan menjadi rujukan bagi moral awareness parapebisnis Muslim untuk menentukan prinsip-prinsip yang dianut dalam menjalankan bisnisnya. (Budi Untung, 2012: 6981).

\section{a. Unity (Persatuan)}

Alam semesta, termasuk manusia, adalah milik Allah, yang memiliki kemahakuasaan (kedaulatan) sempurna atas makhlukmakhluk-Nya. Konsep tauhid (dimensi vertikal) berarti Allah sebagai Tuhan Yang Maha Esa menetapkan batas-batas tertentu atas perilaku manusia sebagai khalifah, untuk memberikan manfaat pada individu tanpa mengorbankan hak-hak individu lainya.

Masudul Alam Choudhury dalam pemaparanya mengenai endogeneity of ethics in islamic socio-scientific order menyatakan bahwa Ibnu Arabi dan para filsuf atomism dari arsharites menyakini bahwa mencermati keberaturan segala sesuatu di alam semesta ini berarti dapat menembus esensi dari keesaan Tuhan (the essence of the Oneness of Gold). (Choudhury, 1998: 97).

Hal ini berarti pranata sosial, politik, agama, moral, dan hukum yang mengikat masyarakat berikut perangkat institusionalnya disusun sedemikian rupa dalam sebuah unit bersistem terpadu untuk mengarahkan setiap individu manusia, sehingga mereka dapat secara baik melaksanakan, mengontrol, serta mengawasi aturan-aturan tersebut. Berlakunya aturan-aturan ini selanjutnya akan membentuk ethical organizational climate tersendiri pada ekosistem individu dalam melakukan aktivitas ekonomi. Aturan-aturan itu sendiri bersumber pada kerangka konseptual masyarakat dalam hubungan vertikal dengan kekuatan tertinggi (Allah Swt.), dan hubungan horizontal dengan kehidupan srsama manusia dan alam semesta secara keseluruhan untuk menuju tujuan akhir yang sama. (Faisal Badroen, 2006; 90).

b. Equilibrium (Keseimbangan)

Dalam beraktivitas di dunia kerja dan bisnis, Islam mengharuskan untuk berbuat adil, tidak terkecuali pada pihak yang tidak disukai. Pengertian adil dalam Islam diarahkan agar hak orang lain, hak lingkungan sosial, hak alam semesta dan hak Allah dan RasulNya berlaku sebagai stakeholder dari perilaku adil seseorang. Semua hak-hak tersebut harus ditempatkan sebagaimana mestinya (sesuai aturan syariah). Tidak mengakomodir salah satu hak datas, dapat menempatkan seseorang tersebut pada kezaliman. Karenanya, orang yang adil akan lebih dekat kepada ketakwaan.

Berlaku adil akan dekat dengan takwa, karena itu dalam perniagaan (tijarah), Islam melarang untuk menipu walaupun hanya 'sekadar' membawa sesuatu pada kondisi yang menimbulkan keraguan sekalipun. Kondisi ini dapat terjadi seperti adanya gangguan pada mekanisme pasar atau karena adanya informasi penting mengenai transaksi yang tidak diketahui oleh salah satu pihak (asyimetric information). Gangguan pada mekanisme pasar dapat berupa gangguan dalam penawaran dan gangguan dalam permintaan.

\section{c. Free Will (Kehendak Bebas)}

Konsep Islam memahami bahwa institusi ekonomi seperti pasar dapat berperan efektif dalam kehidupan ekonomi. Hal ini dapat berlaku bila prinsip persaingan bebas dapat berlaku secara efektif, dimana pasar tidak mengharapkan adanya intervensi dari pihak manapun, tidak terkecuali negara dengan otoritas penentuan harga atau private sektor dengan kegiatan monopolistik.

Manusia memiliki kecenderungan untuk berkompetisi dalam segala hal, tidak terkecuali kebebasan dalam melakukan kontrak dipasar. Oleh sebab itu, pasar seharusnya menjadi cerminan dari berlakunya dari hukum penawaran dan permintaan yang direpresentasikan oleh harga, padar tidak terdistorsi oleh tangan-tangan yang sengaja mempermainkanya. Bagi Smith bila setiap individu diperbolehkan mengejar kepentinganya sendiri tanpa adanya campur tangan pihak pemerintah, maka ia seakan-akan dibimbing oleh tangan yang tidak tampak (the invisible hand), untuk mencapai yang terbaik pada masyarakat.

\section{d. Responsibility}

Aksioma tanggung jawab individu begitu mendasar dalam ajaran-ajaran Islam. Terutama jika dikaitkan dengan kebebasan ekonomi. Penerimaan pada prinsip tanggung jawab individu ini berarti setiap orang akan diadili secara personal di hari kiamat kelak. Tidak ada satu cara pun bagi seseorang untuk melenyapkan perbuatan-perbuatan jahatnya kecuali dengan memohon ampunan Allah dan melakukan perbuatan-perbuatan yang baik (amal saleh). Islam sama sekali tidak mengenal konsep dosa warisan, (dan karena itu) tidak ada seorang pun bertanggung jawab atas kesalahan-kesalahan orang lain.

Setiap individu mempunyai hubungan langsung dengan Allah. Tidak ada perantara sama sekali. Nabi sendiri hanyalah seorang 
utusan (rasul) atau kendaraan untuk melewatkan petunjuk Allah yang diwahyukan untuk kepentingan umat manusia. Ampunan harus diminta secara langsung dari Allah. Tidak ada seorang pun memiliki otoritas untuk memberikan keputusan atas nama-Nya. Setiap individu mempunyai hak penuh untuk berkonsultasi dengan sumber-sumber Islam (Al-Qur'an dan Sunnah) untuk kepentinganya sendiri. Setiap orang dapat menggunakan hak ini, karena hal ini merupakan landasan untuk melaksanakan tanggung jawabnya kepada Allah.

e. Benevolence

Ihsan (benevolence), artinya melaksanakan perbuatan baik yang dapat memberikan kemanfaatan kepada orang lain, tanpa adanya kewajiban tertentu yang mengharuskan perbuatan tersebut, atau dengan kata lain beribadah dan berbuat baik seakanakan melihat Allah, jika tidak mampu, maka yakinlah Allah melihat. Jika keadilan dapat menyelamatkan lingkungan sosial dari tindakan-tindakan yang tidak diinginkan dan kegetiran hidup, maka ke-ihsan-an justru membuat kehidupan sosial ini menjadi manis dan indah.

Problematika yang terjadi sesama Muslim dalam aktivitas perekonomian saat ini, selalu saja disebabkan oleh karena kita kerap meninggalkan ajaran islam, sehingga lantas saja memosisikan kaum Muslimin dalam keadaan tertuduh bahwa mereka tidak mampu menjalankan proyek dan mengelola bisnis dan transaksi. Kemudian pada saat yang sama, kondisi seperti ini justru memberikan kesempatan kepada musuh-musuh Islam untuk menuduh Islam dengan pernyataan bahwa syariat Islam tidak mampu untuk menjalankan dan mengelola proyek dalam bidang garapan ekonomi dan keuangan.

\section{MetodePenelitian}

Penggunaan metode merupakan suatu keharusan mutlak dalam penelitian. Di samping untuk mempermudah penelitian juga untuk menjadikan penelitian lebih efektif dan rasional guna mencapai hasil penelitian yang lebih optimal. (Sutrisno Hadi, 1990: 9).

Penelitian ini sepenuhnya merupakan riset kepustakaan (library research), sebab kajiannya diarahkan kepada tinjauan hukum Islam terhadap penangkaran burung walet, dan hukum mengkonsumsi sarang walet. (Mastuhu dkk, 2000: 119). Pendekatan yang digunakan dalam penelitian ini adalah pendekatan normatif. Jenis data dalam penelitian ini adalah kualitatif.
Adapun teknik pengumpulan data dalam penelitian ini, karena penelitian ini bersifat penelitian pustaka, maka metode yang dipergunakan untuk memperoleh data yang dikehendaki adalah dengan cara mencari dan menggali referensi yang ada kaitannya dengan masalah yang diteliti, baik yang berbentuk buku, artikel maupun dalam bentuk pemberitaan di media massa. Pengumpulkan data dalam penelitian ini melalui beberapa tahap, yaitu; pertama, studi kepustakaan atau observasi literatur. Metode ini dipergunakan untuk meneliti literatur atau tulisan-tulisan yang ada hubungannya dengan pokok permasalahan yang dibahas. Kedua, literatur-literatur yang ada diklasifikasikan sesuai dengan hubungannya dengan penelitian. Ketiga, setelah itu dilakukan penelaahan yakni dengan cara membaca, mempelajari, atau mengkaji literatur-literatur yang mengemukakan masalah-masalah yang berkaitan dengan penelitian. Prinsipnya teknik pengumpulan data ini digunakan untuk menggambarkan masalah penelitian secara alamiah. (Mastuhu dkk, 2000: 126).

Adapun teknik analisis data yang digunakan adalah teknik content analysis (analisa isi). Teknik analisis ini diawali dengan mengkompilasi berbagai dokumen terkait kerangka teoritis tentang hukum memelihara burung dan kriteria hewan yang halal dan haram menurut hukum Islam, baik menurut ulama klasik maupun kontemporer. Kemudian dari hasil tersebut, selanjutnya dikaji isinya (content), baik terkait kata-kata (word), makna (meaning), simbol, ide, tema-tema dan berbagai pesan lainnya yang dimaksudkan dalam masing-masing pendapat tersebut.

\section{Hasil dan Pembahasan}

\section{Penangkaran Burung Walet erspektif Hukum Islam}

Banyak di antara kita yang bertanya-tanya tentang hukum memelihara burung dalam sangkar untuk didengar suaranya dan menjual belikan burung. Ada yang berpendapat bahwa hal tersebut dilarang karena telah membatasi kehidupan salah satu makhluk ciptaan Allah dengan cara mengurungnya, namun ada juga sebagian lainnya yang membolehkannya. Lalu bagaimana Islam memandang permasalahan tersebut? Mayoritas ulama membolehkan memelihara burung dengan syarat; pertama, dipenuhi kebutuhan makannya. Kedua, burung tersebut bukan tergolong burung yang akan mati jika dikurung. Sebagaimana penjelasan ahli, ada beberapa burung yang jika dikurung akan mati. Burung semacam ini tidak boleh dipelihara. Dalilnya adalah hadis yang 
diriwayatkan oleh Bukhari dan Muslim dari Abu Hurairah mengenai perempuan yang masuk neraka gara-gara seekor kucing. Nabi bersabda: "Dia tidak memberi makanan untuk kucing tersebut ketika mengurungnya. Tidak pula dia biarkan kucing tersebut untuk cari makan sendiri." Imam Syaukani dalam Nail al-Authar mengatakan bahwa hadits ini digunakan sebagai dalil tentang keharaman mengurung kucing atau hewan peliharaan lainnya tanpa memberi makan dan minum, sebab hal tersebut merupakan bentuk penyiksaan pada makhluk Allah.

Sejumlah ulama mengatakan bahwa hadis di atas menunjukkan bolehnya mengurung hewan asalkan kebutuhan makanannya dipenuhi, sehingga jika ada yang memelihara dan mengurung kambing, kucing, atau burung dan kebutuhan makanannya dipenuhi dan diperhatikan maka hukumnya adalah diperbolehkan.

Dalil yang lain adalah hadis yang diriwayatkan oleh Bukhari dan Muslim dari Anas yang menceritakan bahwa Nabi melewati seorang anak kecil yang bermain-main dengan seekor burung kecil. Setelah itu Nabi kembali menemuinya lagi, namun beliau jumpai anak kecil tersebut menangis. Nabi berkata kepadanya: "Wahai Abu Umair (panggilan untuk anak tersebut), apa yang dilakukan oleh burungmu?" Dalam hadis ini Nabi membiarkan anak tersebut memelihara dan bermain dengan burung yang dia pelihara. Nabi pun tidak memerintahkan keluarganya agar melepas burung tersebut. Jika boleh memelihara burung berarti burung adalah sesuatu yang bernilai sehingga diperbolehkan juga menjual atau membelinya. Kesimpulannya, memperdagangkan burung hukumnya boleh. (Ibnu Hajar al-'Asqalani, Fath al-Bari, 10/601).

Dari uraian diatas dapat ditarik kesimpulan bahwa memelihara burung itu hukumnya diperbolehkan, termasuk memelihara burung walet meskipun hanya sekedar untuk menikmati keindahan suaranya,bulu-bulunya atau sekedar untuk bersenang-senang asalkan pemilik burung merawatnya dengan baik, dengan mencukupi keperluan makanan dan minumannya.

Salah satu diantara nikmat yang Allah berikan untuk manusia adalah binatang. Allah Swt berfirman: "Dan Dia telah menciptakan binatang ternak untuk kamu. Padanya ada (bulu) yang menghangatkan dengan berbagai-bagai manfaat, dan sebagiannya ada yang boleh kamu makan. Kamu memperoleh pandangan yang indah darinya, ketika kamu membawanya kembali ke kandang dan ketika kamu melepaskannya ke tempat penggembalaan, dan ia memikul bebanbebanmu ke suatu negeri yang kamu tidak sanggup sampai kepadanya, melainkan dengan kesukaran-kesukaran diri. Sesungguhnya
Tuhanmu benar-benar Maha Pengasih lagi Maha Penyayang, dan (dia telah menciptakan) kuda, bagal dan keledai, agar kamu menungganginya dan menjadikannya perhiasan. Allah menciptakan apa yang kamu tidak mengetahuinya. (QS. A1Nahl [16]: 5-8).

Allah tegaskan dalam ayat di atas, bahwa salah satu manfaat hewan piaraan adalah 'kamu memperoleh pandangan yang indah padanya." Sekalipun hewan ini tidak ditunggangi, dia bisa menjadi pemandangan menarik bagi pemiliknya. Dirawat hanya untuk dipandang dan dijadikan hiasan. Fungsi semacam ini ada pada burung peliharaan.

Burung walet merupakan burung pemakan serangga yang bersifat aerial dan suka meluncur. Burung ini berwarna gelap, terbangnya cepat dengan ukuran tubuh sedang/kecil, dan memiliki sayap berbentuk sabit yang sempit dan runcing, kakinya sangat kecil begitu juga paruhnya dan jenis burung ini tidak pernah hinggap di pohon. Burung walet mempunyai kebiasaan berdiam di gua-gua atau rumah-rumah yang cukup lembab, remang-remang sampai gelap dan menggunakan langit-langit untuk menempelkan sarang sebagai tempat beristirahat dan berbiak.

Adapun cara penangkaran sarang burung walet adalah dengan cara mendirikan bangunan tinggi seperti ruko bertingkat, lalu ruko itu tidak diberikan kaca pada jendelanya dan dibiarkan terbuka. Memancing datangnya burung walet untuk masuk ke dalam ruko tersebut dengan dengan suara musik yang menggunakan kaset dengan tape. Burung walet tidak dipelihara seperti unggas yang lainnya yang dipelihara oleh pemiliknya. Burung walet bersifat bebas dan sesukanya saja ingin di mana bersarang.

Ada tiga jenis burung walet yang umum dikenal, yaitu; Collocalia Fuciphaga, Collocalias Maxima, dan Collocalia Esculenta. Ada satu jenis burung walet lagi, yaitu Collocalia Germani, tetapi menurut pendapat ahli Collocalia Germani termasuk dalam spesies Collacalia Fuciphaga, sehingga bukan merupakan spesies tersendiri. Collocalia Germani tidak ditemukan di Indonesia, namun burung tersebut ditemukan di negara lain di Asia seperti Vietnam. Collocalia Fuciphaga adalah jenis burung yang banyak dicari karena burung tersebut bersarang putih. Collocalia Fuciphaga ditemukan di Cina bagian Selatan dan Asia Tenggara termasuk Indonesia. Di Sumatra dan Kalimantan burung tersebut bisa hidup sampai ketinggian 2.800 meter di atas permukan laut, tetapi di Jawa dan Bali burung ini biasanya hidup dekat pantai di dalam gua yang gelap dan dalam. Burung tersebut kirakira berukuran $12 \mathrm{~cm}$, dadanya berwarna hitam kecoklatan dan warna punggung lebih kelabu. 
Ekor burung ini bercabang, paruhnya berwana hitam dan kakinya juga berwarna hitam. (Eka Adiwibawa, 2000: 68-69).

Collocalia Fuciphaga dan Collocalia Maxima tidak dapat dibedakan dari Collocalia Esculenta kecuali dari sarangnya Collocalia Maxima membuat sarang dengan air liur seperti Fuciphaga, tetapi sarangnya bercampur dengan bulu burung sehingga harga sarangnya lebih rendah. Namun demikian, karena keduanya membuat sarang dengan air liur dan sarangnya hanya sedikit berbeda, orang Indonesia menyebut Collocalia Fuciphaga dan Collocalia Maxima dengan nama burung walet. (Eka Adiwibawa, 2000: 69).

Harga sarang burung walet antara 7-14 juta Rupiah per kilogram, tergantung kualitasnya. Ada empat kelas sarang burung walet yang dihasilkan di Indonesia, yaitu: (1) Kelas yang tertinggi adalah sarang yang paling bersih, warnanya sangat putih dan tidak ada bulu burung. Sarang seperti ini adalah sarang yang paling banyak diminta dari pemilik gedung walet karena harga sarang ini paling tinggi, kira-kira 1214 juta Rupiah per kilogram. (2) Sarang walet kelas dua tidak terbuat dari bulu burung, tetapi sarangnya masih sedikit kotor. Kotornya bisa dikarenakan burung tersebut bertelur, tetapi telurnya kemudian diambil setelah menetas. Harga sarang walet kelas dua ini berkisar 10-12 juta Rupiah per kilogram. (3) Kelas ketiga agak kotor, tetapi terbuat dari air liur dan bulu burung. Sarang kelas tiga berharga kira-kira 8-9 juta rupiah per kilogram. (4) Kelas keempat adalah sarang yang paling kotor, sehingga harganya paling murah. Sarangnya sangat kotor karena telur walet yang sudah ditetaskan atau terbuat dari air kotor. Harga sarang kelas empat ini kira-kira 7-8 juta Rupiah per kilogram.

Di samping kelas-kelas sarang berwarna putih, ada juga sarang burung walet yang berwarna merah. Sarang merah asli adalah sarang yang jarang didapat karena sarangnya terbuat dengan campuran air liur dan darah, tetapi sarang ini sangat jarang sehingga harganya merupakan yang tertinggi, yaitu lebih dari 14 juta Rupiah per kilogram. Sarang burung walet juga bisa dibuat agar berwarna merah, tetapi warnanya sedikit berbeda dengan sarang merah asli. Untuk membuat sarang berwarna merah di dalam gedung walet harus mempunyai banyak air dan diberi campuran amoniak ke dalam airnya. Amoniak membantu sarang menjadi warna merah, tetapi harga sarang ini tidak setinggi sarang merah asli. Harga sarang yang dibuat merah masih tergantung dengan kualitas sarang, tetapi sedikit lebih mahal dari pada sarang putih biasa. (Arief Budiman, 2005: 78).

\section{Mengkonsumsi Sarang Burung Walet Perspektif Hukum Islam}

Sarang burung walet memiliki komposisi berupa air liur walet, yang mengandung: (1) Glikoprotein, untuk meregenerasi sel-sel tubuh dan kulit. (2) Lemak. (3) Air. (4) Karbohidrat. (5) Protein. (6) 17 asam amino esensial, semi esensial, dan non-esensial. (7) 6 Mineral penting, yaitu; kalsium, zat besi, fosfor, kalium, dan natrium. (8) Zat Azitothymidine, senyawa turunan yang dihasilkan dari protein yang terkandung di dalam air liur burung walet dapat melawan penyakit AIDS. (Arief Budiman, 2005: 83).

Sarang burung walet, memiliki banyak manfaat dan khasiat, yaitu sebagai berikut: (1) Melawan radikal bebas, karena kaya akan kandungan asam amino dan antioksidan. (2) Meningkatkan reproduksi sel tubuh. (3) Meningkatkan sistem kekebalan tubuh. (4) Meningkatkan nafsu makan. (5) Membantu memperkuat paru-paru dan ginjal. (6) Mencegah kanker dan membantu pengobatan pasien penderita kanker. (7) Meningkatkan fungsi jantung. (8) Bermanfaat bagi penderita hipertensi karena dapat menurunkan tekanan darah. (9) Membantu mengatur pasokan cairan dalam tubuh. (10) Meredakan dan memulihkan bermacam penyakit seperti batuk, influenza, asma dan infeksi tenggorokan. (11) Meningkatkan kesehatan dan anti bodi ibu hamil beserta janin yang dikandungnya. Baik juga bagi kesehatan ibu yang baru melahirkan. (12) Mengencangkan dan mencerahkan kulit., juga dapat membantu dalam pencegahan penuaan dini. (13) Meningkatkan sistem kekebalan tubuh pada anak. (Hendri Mulia, 2010: 67).

Lalu bagaimanakah pandangan Islam mengenai hukum mengkonsumsi sarang burung walet, mengingat bahwa kandungan sarang burung walet adalah berupa air liur burung tersebut. Untuk menjawab pertanyaan tersebut, berikut dalil-dalil yang memiliki korelasi dan rlevansi dengan status hukum air liur walet tersebut. Pertama, firman Allah Swt: “...dan ia (Nabi) menghalalkan bagi mereka segala yang baik dan mengharamkan bagi mereka segala yang buruk..." (QS. Al-A'raf [7]: 157). Hadis Nabi dari Jabir bin Abdillah, suatu ketika Nabi ditanya: "Apakah kami boleh berwudhuk dari air yang bekas minumnya keledai? Nabi menjawab: "Ya, boleh, juga dari bekas binatang buas." (HR. AlBaihaqi). Ketiga, konsensus (ijma') ulama. Para ulama sepakat bahwa sisa air minum dari hewan yang dapat dimakan dagingnya hukumnya suci, boleh meminum (dari air yang bekas diminum hewan tersebut), dan boleh juga berwudhu' dengannya. 
Dalam hal ini pun Majelis Ulama Indonesia (MUI) telah memfatwakan (Fatwa MUI/No.2/ Tahun 2012) yang intinya adalah bahwa sarang burung walet suci dan halal. Halal juga membudidayakan sarang burung tersebut. Namun apabila sarang tersebut terkena najis seperti kotoran burung tersebut, maka sarang burung tersebut haruslah disucikan secara syar'i. Air liurnya halal dikonsumsi, karena air liur walet tidak najis, dan tidak ada dalil yang menajiskannya, bahkan terdapat dalil yang menunjukkan kesuciannya. Dalam sebuah hadis disebutkan: Dari Amr bin Kharijah berkata: "Nabi berkhutbah kepada kami di Mina dan beliau berada di atas kendaraannya dan liur kendaraannya mengalir di pundakku." (HR. Tirmidzi, Ibnu Majah, dan Ahmad). Al-Shan'ani berkomentar, hadis ini menunjukkan bahwa liur hewan yang boleh dimakan dagingnya adalah suci, bahkan diceritakan bahwa hal itu merupakan kesepakatan ulama, apalagi hal ini sesuai dengan kaidah asal. (Al-Shan'ani, Subul al-Salam, 1/77). Dengan demikian dapat disimpulkan bahwa memelihara burung walet hukumnya boleh dan hukum air liurnya halal.

Hasil kajian LPPOM MUI, pada prinsipnya hukum sarang burung walet dibolehkan, karena sarang burung tersebut dihasilkan dari bagian dalam perut burung sehingga tidak ada masalah. Namun, yang menjadi perhatian LPPOM MUI adalah bagaimana proses pembersihan dari sarang burung walet tersebut, karena tidak menutup kemungkinan di sarang tersebut tercampur dengan sesuatu yang najis, seperti kotoran burung itu sendiri, mungkin juga lingkungan yang membawa kotoran ke dalam sarang. Pengaruh luar ini yang bisa membuat sarang burung walet menjadi tidak halal. Oleh karena itu, proses pencucian sarang burung walet harus diperhatikan dengan serius. Jangan sampai ada kotoran yang masih melekat di sarang burung, karena kalau sarang burung masih bercampur dengan kotoran menjadi najis, tidak halal untuk dimakan. Sebaliknya, pencucian yang benar-benar bersih, maka halal hukumnya.

\section{Kesimpulan}

Dari uraian diatas dapat ditarik kesimpulan bahwa memelihara burung itu hukumnya diperbolehkan, termasuk memelihara burung walet meskipun hanya sekedar untuk menikmati keindahan suaranya,bulu-bulunya atau sekedar untuk bersenang-senang asalkan pemilik burung merawatnya dengan baik, dengan mencukupi keperluan makanan dan minumannya, dan pada prinsipnya hukum mengkonsumsi sarang burung walet dibolehkan (halal), karena sarang burung tersebut dihasilkan dari bagian dalam perut burung tersebut.

\section{Daftar Pustaka}

Adiwibawa, Eka, Pengelolaan Rumah Walet, Yogyakarta: Kanisius, 2000.

Ahmad, Mustaq, Etika Bisnis Dalam Islam, Jakarta: Pustaka Al-Kautsar, 2001.

Al-'Asqalani, Ibnu Hajar, Fath al-Bari, Beirut: Dar al-Fikr, 1407 H/ 1987 M.

Alma, Buchari, Ajaran Islam dalam Bisnis, Bandung: CV. Alfabeta, 2002. , Dasar-Dasar Etika Bisnis Islami, Bandung: CV. Alfabeta, 2003.

Al-Shan'ani, Subul al-Salam, Beirut: Dar al-Fikr, 1407 H/ 1987 M.

Al-Syarbini, Khtib Mughni al-Muhtaj, Beirut: Dar al-Fikr, 1407 H/ 1987 M.

Al-Syaukani, Nail al-Authar, Beirut: Dar al-Fikr, 1407 H/ 1987 M.

Badroen,Faisal, Etika Bisnis Dalam Islam, Jakarta, Kencana, 2006.

Budiman, Arief, Budidaya \& Bisnis Sarang Walet, Jakarta: Penebar Swadaya, 2005.

Hadi, Sutrisno, Metodologi Research, Yogyakarta: Andi Offset, 1990.

Ibnu Hazm, al-Muhalla, Beirut: Dar al-Fikr, 1407 H/ $1987 \mathrm{M}$.

Ibnu Qudamah, al-Mughni, Beirut: Dar al-Fikr, 1407 H/ 1987 M.

Ibnu Rusyd, Bidayah al-Mujtahid, Beirut: Dar alFikr, $1405 \mathrm{H} / 1985 \mathrm{M}$.

Mulia, Hendri, Cara Jitu Memikat Walet, Jakarta: Agro Media Pustaka, 2010.

Nazaruddin dan Antonius Widodo, Sukses Merumahkan Walet, Jakarta: Penebar Swadaya, 2005.

Tim Penyusun, Fatawa Lajnah Daimah, Riyadh: Kementrian Wakaf dan Urusan Haji, 1409 H/ 1989 M.

Tim Penyusun, Mausu'ah al-Kuwaitiyyah, Kuweit: Kementrian Wakaf Kuweit, 1409 H/ 1989 M.

Untung, Budi, Hukum dan Etika Bisnis, Yogyakarta: ANDI, 2012. 